\title{
Optimizing characteristic of spirulina-polyvinyl alcohol (PVA) bioplastic through protein deformation with variation of heating time and solvent's pH
}

\author{
Dianursanti $^{1, *}$, Misri Gozan ${ }^{1}$, Larasati Windiani ${ }^{1}$, and Hassel Angelyn Sabathini ${ }^{1}$ \\ ${ }^{1}$ Departement of Chemical Engineering Faculty of Engineering Universitas Indonesia Depok 16424, Indonesia
}

\begin{abstract}
Plastics that are widely used today are still made of synthetic polymers that are difficult to degrade by soil microorganisms. The development of natural polymer such as protein blend with synthetic polymer for bioplastic manufacturing continues. This study will utilize Spirulina platensis blended with synthetic polymers with heating and sonication as pre-treatment to optimize the characteristic. In this research, $2.5 \mathrm{~g}$ of Spirulina platensis powder dissolved in alkali and distillate water with $\mathrm{pH}$ variation of $7,8.5,10$, and 11 , then plasticized by glycerol and heating at $70^{\circ} \mathrm{C}$ with heating time variation of 30,60, and 120 minutes. After that, blending with $2.5 \mathrm{~g}$ polyvinyl alcohol. Mixed solution then dried and formed as flex bar. Based on the results of solvent $\mathrm{pH}$ variation, the degree of acidity of the best solvent to produce optimum mechanical properties is a solvent with a $\mathrm{pH}$ of 10 . The best heating time to produce optimum mechanical properties is 60 minutes at a solvent $\mathrm{pH}$ above 8.5. If using a solvent $\mathrm{pH}$ below 8.5 , the best heating time is 120 minutes. Degree of solvent acidity is the most influential parameter on the bioplastic mechanical properties of Spirulina-PVA while the heating time has no significant effect.
\end{abstract}

\section{Introduction}

Plastics that have been used in daily life today are made of synthetic polymers that are difficult to degrade by environment because of its not capable to digest by microorganism and even can release toxic substances. Non-biodegradable plastics are widely made of petroleum which is non-renewable fossil fuel. Non-biodegradable plastics will cause accumulation of waste that increase environmental problems in landfill area. Indonesia is the second biggest in the world of plastic waste to the sea which reached 187.2 million tons after China reached 262.9 million tons [6]. The use of non-biodegradable plastic leads to environmental problems and this situation has dramatically increased with the world's growing population. The production and combustion of conventional plastics create hazardous compounds, which are harmful to human health. Therefore, an idea to produce biodegradable plastics becomes very promising, due to the big challenge to replace the use of petroleumderived plastics [18]. Some efforts have done to process this plastic waste such as incineration, sorting, conversion of waste materials into raw materials, and collection for creative industries. However, these ways require a lot of money. This non-biodegradable plastic problem leads to an interest in research of biodegradable plastic, or also called Bioplastic.

Bioplastics or organic plastics are form of plastics derived from renewable biomass sources such as vegetable oil, corn starch, pea starch, and protein. These natural materials can be produced from several types if bacteria and algae as food storage [5]. Biodegradable plastic is designed to facilitate the degradation of enzymatic reaction of microorganisms such as bacteria and fungi [1]. Bioplastic from algae can be derived from algae biomass or direct algae. Some variations of bioplastic made from algae can be a hybrid plastic, cellulose-based plastic, Poly-Lactic Acid (PLA), BioPolyethylene.

Spirulina platensis is rich in protein. Protein content in dried Spirulina platensis about $60-71 \%$ [7]. The most important component of algae that helps the formation of polymers is proteins. If the synthetic polymer contained identical long chain monomer that is covalently bound. Thus, proteins in natural polymers of algae contain complex hetero polymers, comprising 20 different amino acids. Proteins are a combination of hydrophobic, hydrophilic, acidic, and basic parts of the chain and have a great range of intermolecular interactions compared to synthetic homo-polymers.

In this research, Spirulina platensis powder dissolved

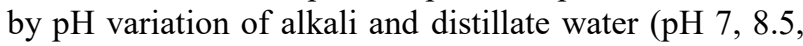
$10,11)$ and heating time variation that leads to protein deformation inside the slurry which are 30,60 , and 120 minutes. The goals of this research is optimizing the characteristics of bioplastic from Spirulina-PVA through protein deformation by heating and solvent.

\footnotetext{
* Corresponding author: dianursanti@yahoo.com
} 


\section{Methods}

\subsection{Materials}

Dried Spirulina platensis biomass was provided by POLARIS. Glycerol was used as received from Merck. Synthetic polymer has been prepared by melting PVA in variation of alkali and distillate water. Water that used to dissolve Spirulina platensis powder before blended with PVA is distillate water $(\mathrm{pH} 7)$ and alkali water $(\mathrm{pH} 8.5$, $10,11)$.

\subsection{Preparation of Spirulina-PVA Films}

Spirulina platensis-Polyvinyl Alcohol ternary bled functional food packaging films were prepared by solvent casting method. Film solution were prepared by dissolving 2,5 g of dried Spirulina platensis into $20 \mathrm{ml}$ of distillate water $(\mathrm{pH} 7)$ and variation of alkali water $(\mathrm{pH}$ $8.5,10,11)$ then sonicated for about $30 \mathrm{~min}$ at $25^{\circ} \mathrm{C}$ using ultra-sonicator Satorius with sonication frequency about $53 \mathrm{kHz}$. Before heating, $2 \mathrm{ml}$ glycerol as plasticizer added into spirulina slurry. Heating the spirulina-glycerol solution with mixing vigorously with variation heating time 30, 60, and $120 \mathrm{~min}$. While Spirulina -glycerol heated, 2,5 g polyvinyl alcohol melted with $10 \mathrm{ml}$ distillate or alkali water with $\mathrm{pH}$ suited as Spirulina solution. Plasticized Spirulina added into melted PVA and mixing at $60^{\circ} \mathrm{C}$ for about $15 \mathrm{~min}$. a brown-green and uniform film fluid was obtained. All the film solutions were cast onto glass plate $(20 \mathrm{~cm} \times 15 \mathrm{~cm})$ and were dried for about $24 \mathrm{~h}$ at room temperature and peeled off from the plate to obtain a dried film.

\subsection{Mechanical Properties}

The tensile strength test was performed using ASTM D882-12 test standard and Shimadzu AGS-10 kNG test equipment. The number of specimens tested from each sample amounted to 5 specimens. Conditioning of pre-test samples includes temperatures of $23^{\circ} \mathrm{C}$ and humidity by $50 \%$ for more than 40 hours. Operating conditions during the test include a speed of $50 \mathrm{~mm} / \mathrm{min}$ with a distance of $100 \mathrm{~mm}$ grip under environmental conditions with a temperature of $23^{\circ} \mathrm{C}$ and $55 \%$ moisture. Tensile strength and elongation tests were conducted at the Polymer Technology Center of BPPT, Serpong.

Each sample was tested three times and averaged. Then the TS of the films was calculated using the following equation:

$$
T=\frac{F}{S}
$$

In the formula:

Ts-Tensile strength, MPa;

F-The maximum tensile force when the sample breaks, $\mathrm{N}$;

$\mathrm{S}-$ Cross-sectional area of specimen, $\mathrm{m}^{2}$

\subsection{Surface Morphology and FTIR Analysis}

The structure of film morphology was analyzed using scanning electron microscopy. The sample is cut to a certain small size, then coating with platinum for 55 seconds at a current of $30 \mathrm{~mA}$ with a voltage of $20 \mathrm{kV}$. The tool to test this morphology using JEOL JSM-6510 LA SEM with 500x, 1000x, and 2500x magnification. The SEM test was conducted at the Polymer Technology Center of BPPT, Serpong.

Characterization of molecular structures in film specimens was analyzed using Fourier Transform Infrared. FT-IR testing is done at a resolution of 8 and optical speed of 4 by Thermo Scientific Nicolet iS5. The detector used in this FT-IR test kit is DTGS KBr. FT-IR testing was conducted at the Chemical Engineering Chemical UI Laboratory.

\subsection{Thermogravimetric Analysis (TGA)}

The thermal test is carried out according to the ASTM E1131-14 test standard using a Thermal Gravimetry Analyzer-Mettler Toledo test apparatus. The SEM test was conducted at the Polymer Technology Center of BPPT, Serpong. The weight of the tested sample was 20 mg. Operating conditions during testing include: $50^{\circ} \mathrm{C}$ $\rightarrow 600^{\circ} \mathrm{C}$, heating rate of $10^{\circ} \mathrm{C} / \mathrm{min}$ and $\mathrm{N}_{2}$ rate of $50 \mathrm{ml}$ $/ \mathrm{min} ; 600^{\circ} \mathrm{C}(5 \mathrm{~min}), \mathrm{N}_{2}$ rate of $50 \mathrm{ml} / ; 600^{\circ} \mathrm{C} \rightarrow 900^{\circ} \mathrm{C}$, with a heating rate of $10^{\circ} \mathrm{C} / \mathrm{min}$ and an $\mathrm{O}_{2}$ rate of $50 \mathrm{ml}$ $/ \mathrm{min}$. The derivative form of TGA (DTG) was obtained by calculating the differentials of the TGA values using a central finite difference method as follows:

\section{Result and Discussion}

\subsection{Effect of Solvent's PH to Tensile Strength of Spirulina-PVA Bioplastic}

To make spirulina mostly contain protein similar to plastic, other than that with synthetic polymer like PVA, but also do pre-treatment like heating. Heating to dry Spirulina dissolved in the description solvent to make the protein in Spirulina denatured from the plasma. When a non-covalent bond in the protein is exposed, it will be easier for the heat to break the structure to stabilize the three-dimensional structure of the protein.

Table 1. Tensile Strength and Elongation Data on Variation of Solvent's pH at Heating Time 30 minutes

\begin{tabular}{|c|c|c|}
\hline $\begin{array}{c}\text { Degree of } \\
\text { Solvent Acidity } \\
(\mathbf{p H})\end{array}$ & $\begin{array}{c}\text { Tensile } \\
\text { Strength } \\
\left(\mathbf{l b f} / \mathbf{c m}^{2}\right)\end{array}$ & $\begin{array}{c}\text { Elongation } \\
\mathbf{( \% )}\end{array}$ \\
\hline 7 & $69,02 \pm 0,53$ & $56,39 \pm 12,87$ \\
\hline 8,5 & $56,43 \pm 0,56$ & $178,80 \pm 27,30$ \\
\hline 10 & $74,86 \pm 0,49$ & $185,50 \pm 21,12$ \\
\hline 11 & $96,67 \pm 0,71$ & $61,13 \pm 16,42$ \\
\hline
\end{tabular}


Table 2. Tensile Strength and Elongation Data on Variation of Solvent's pH at Heating Time 60 minutes

\begin{tabular}{|c|c|c|}
\hline $\begin{array}{c}\text { Degree of } \\
\text { Solvent Acidity } \\
\text { (pH) }\end{array}$ & $\begin{array}{c}\text { Tensile } \\
\text { Strength } \\
\text { (lbf/cm }\end{array}$ & $\begin{array}{c}\text { Elongation } \\
\mathbf{( \% )}\end{array}$ \\
\hline 7 & $77,33 \pm 0,53$ & $111,80 \pm 26,13$ \\
\hline 8,5 & $62,95 \pm 0,15$ & $215,20 \pm 7,17$ \\
\hline 10 & $83,18 \pm 0,15$ & $210,50 \pm 19,89$ \\
\hline 11 & $88,13 \pm 0,43$ & $82,41 \pm 18,65$ \\
\hline
\end{tabular}

Table 3. Tensile Strength and Elongation Data on Variation of Solvent's $\mathrm{pH}$ at Heating Time 120 minutes

\begin{tabular}{|c|c|c|}
\hline $\begin{array}{c}\text { Degree of } \\
\text { Solvent Acidity } \\
\text { (pH) }\end{array}$ & $\begin{array}{c}\text { Tensile Strength } \\
\left(\mathbf{l b f} / \mathbf{c m}^{2}\right)\end{array}$ & Elongation (\%) \\
\hline 7 & $87,68 \pm 0,39$ & $91,99 \pm 27,65$ \\
\hline 8,5 & $94,87 \pm 0,42$ & $171,60 \pm 22,74$ \\
\hline 10 & $64,30 \pm 0,23$ & $71,58 \pm 11,92$ \\
\hline 11 & $93,97 \pm 0,43$ & $112,40 \pm 15.91$ \\
\hline
\end{tabular}

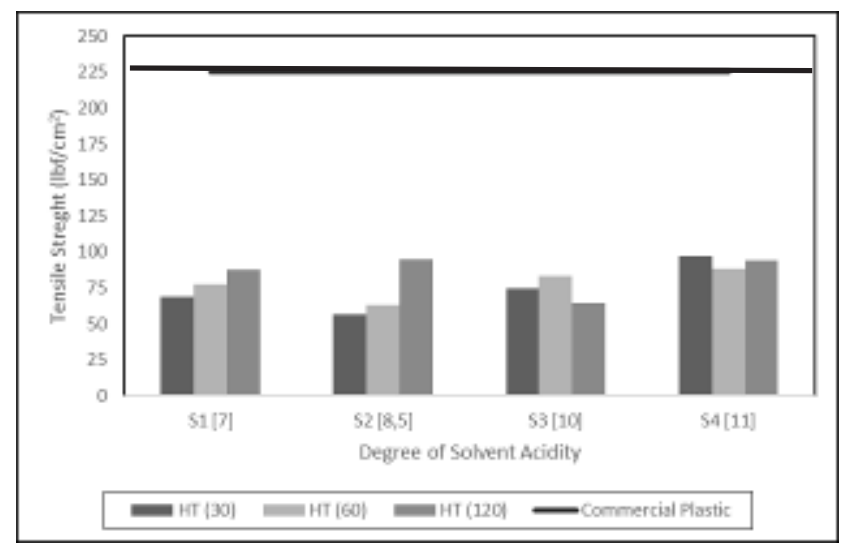

Fig. 1. Effect of Degree of Solvent Acidity on Tensile Strength value of Spirulina-PVA Bioplastic

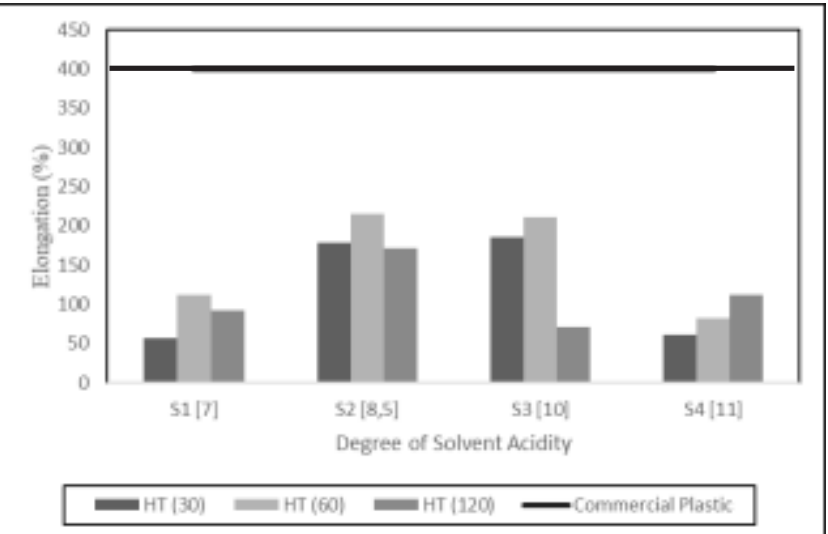

Fig. 2. Effect of Degree of Solvent Acidity on Elongation value of Spirulina-PVA Bioplastic

The large difference in tensile strength based on the difference of $\mathrm{pH}$ on heating 30 and 60 minutes has a resemblance that can be observed in the table and figure 1-2. In the $\mathrm{pH}$ solvents 10 and 11 , the tensile strength values grew larger while at $\mathrm{pH} 7$, the tensile strength value was higher than the tensile strength value at $\mathrm{pH} 8.5$, but lower than the tensile strength value at $\mathrm{pH} 10$ and 11 . This can occur due to the $\mathrm{pH} 7$ solvent, where the positive and negative ions in the solvent are in equilibrium so that this state indicates that the $\mathrm{pH}$ of this solvent is at the isoelectric point of the protein where there will be no ion movement between the solvent and the protein. The dipolar form persists until the $\mathrm{pH}$ reaches a value of 9 when the protonated amino group loses the proton. Although dissolved in different $\mathrm{pH}$, protein molecules remain balanced because of positive and negative ions. This is in accordance with study which shows that protein solubility increases as the $\mathrm{pH}$ value rises [10]. The maximum solubility of proteins is at $\mathrm{pH} 8$ because in this condition, positive and negative ions in the protein interact with water. Solubility of solids in the solvent signifies the stronger the bond between the water-protein so that the resulting film is thicker.

The major differences in elongation are also influenced by differences in $\mathrm{pH}$ and plasticizer disturbance to polymer bonds in proteins that can be observed in Table 1-2 and Figure 2. At pH 7 with a 30 minutes heating time, the amount of intermolecular bonds that may be exposed due to plasticizer disturbance is not as much at $\mathrm{pH} 8.5$ as the solubility of $\mathrm{pH} 7$ is lower than $\mathrm{pH} 8.5$ as evidenced by higher thickness and elongation. At $\mathrm{pH} 10$ and 11, the value of tensile strength increases with the increase of alkaline $\mathrm{pH}$, but the elongation decreases. Reduced thickness indicates reduced solids solubility as $\mathrm{pH}$ increases. The higher the alkaline $\mathrm{pH}$, the less stability is due to the reduced disulfide bond. The disruption of the plasticizer that opens the hydrogen bond and replaces the hydrogen position in the polymer bonds makes the film characteristics more elastic but the voltage resistance becomes lower. It is shown on the graphs and tables that at $\mathrm{pH} \mathrm{10,} \mathrm{the} \mathrm{elongation} \mathrm{and} \mathrm{thickness} \mathrm{are}$ greater, but the value of tensile strength is lower than $\mathrm{pH}$ 11.

In contrast to the data on heating of 30 and 60 minutes, on heating of 120 minutes, the effect of temperature on denaturation is greater than disturbance or $\mathrm{pH}$ of the solvent plasticizer. It can be seen in figures 1 and 2 that the value of tensile strength is directly proportional to elongation. The value of tensile strength at $\mathrm{pH} 11$ is higher than at $\mathrm{pH} 10$ because of negative ions which make stronger protein and water bonds more numerous so denaturation is easier to do. The film structure of this 120 minutes heating is indicated to be more rigid due to the large number of solvent losses so that the bonding between the solvent-plasticizer is denser and intact.

Based on figure 1 it is seen as a comparison for all variations of commercial plastic based LDPE cited from plastic consulting company in the UK that is Smithers Rapra, where minimum tensile strength value is $10 \mathrm{Mpa}$ or equivalent to $224,48 \mathrm{lbf} / \mathrm{cm}^{2}$. In this study, a lower tensile strength value of LDPE commercial plastics is required to develop further. Based on the Indonesian National Standards calibrated from [3] where the value of tensile strength ranged between $2.47-302 \mathrm{MPa}$, the value of tensile strength in this study already meets the minimum standard of tensile strength for plastic 
packaging. However, if based on international standards (ASTM 5336) for biopolymer-based plastics, such as PCL in the UK with a tensile strength value of $190 \mathrm{Mpa}$ and PLA in Japan reaching $2050 \mathrm{Mpa}$, the value of bioplastic tensile strength in this study has not yet met.

For elongation values, the comparator used is commercial plastic based LDPE with an elongation value of $400 \%$. Plastics resulting from this study have a much lower elongation value. However, if based on SNI where the elongation ranges are in the range of $21-220 \%$ quoted in [4], this study results in average elongation values above the minimum standard and slightly below the maximum plastics in Indonesia. Compared with international standard plastics (ASTM 5336) in Japan and the UK at $9 \%$ and above $500 \%$ [2], the elongation value in this study is far below those standards.

\subsection{Effect of Heating Time to Mechanical Properties of Spirulina-PVA Bioplastic}

Table 4. Tensile Strength and Elongation Data on Variation of Heating Time

\begin{tabular}{|c|c|c|}
\hline $\begin{array}{c}\text { Heating Time } \\
\text { (minutes) }\end{array}$ & $\begin{array}{c}\text { Tensile } \\
\text { Strength } \\
\text { (lbf/cm } \mathbf{~})\end{array}$ & $\begin{array}{c}\text { Elongation } \\
\mathbf{( \% )}\end{array}$ \\
\hline 0 & $82,50 \pm 0,72$ & $209,00 \pm 44,10$ \\
\hline 30 & $96,67 \pm 0,71$ & $178,80 \pm 27,30$ \\
\hline 60 & $88,12 \pm 0,43$ & $215,20 \pm 7,17$ \\
\hline 120 & $93,97 \pm 0,45$ & $171,60 \pm 22,74$ \\
\hline
\end{tabular}

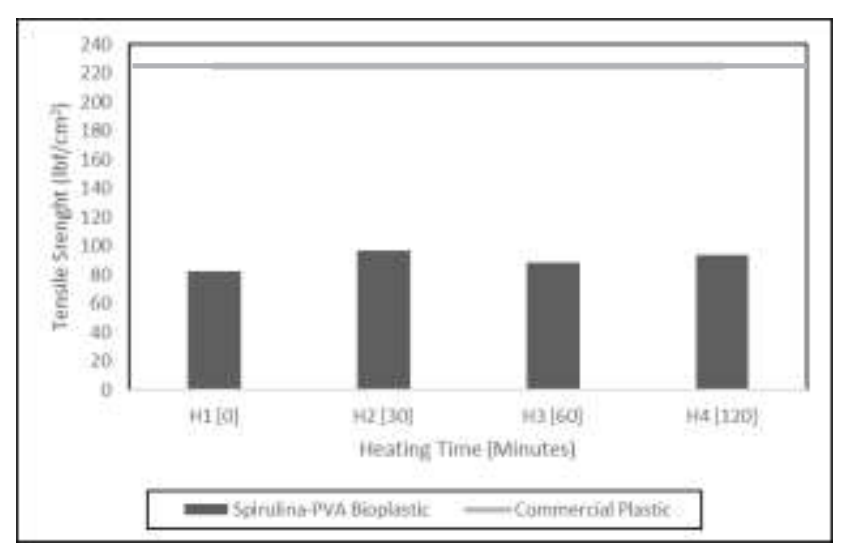

Fig. 3. Effect of Heating Time on Tensile Strength value of Spirulina-PVA Bioplastic

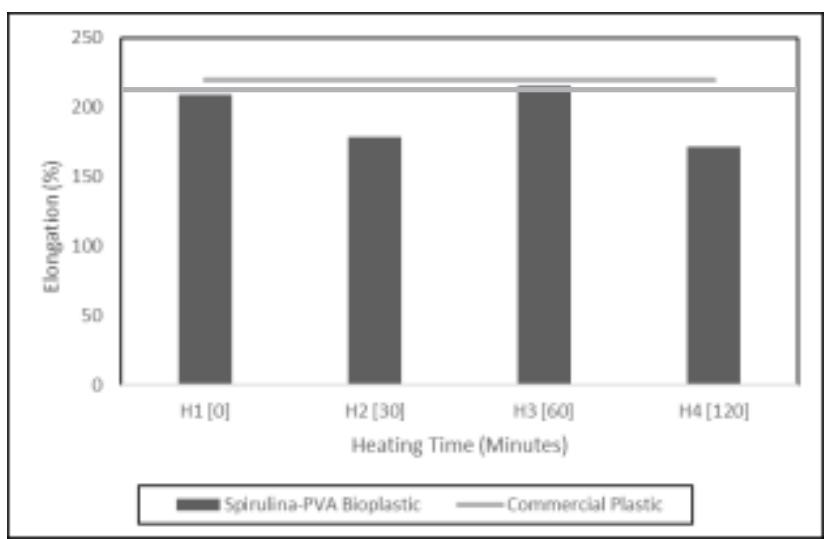

Fig. 4. Effect of Heating Time on Elongation value of SpirulinaPVA Bioplastic

The heat treatment in the bioplastic manufacturing process can affect the insertion process of plasticizer molecules into the polymer chains in proteins. Heat serves to disrupt hydrogen bonding and non-polar hydrophobic interactions. This can happen because heat can increase kinetic energy and cause molecules to vibrate quickly and unconsciously bonds become tenuous. According to the research, the longer the heating takes place, the greater the modulus of elasticity [3]. The elasticity modulus is directly proportional to the size of the elongation because it indicates that the film specimen is getting more elastic. Based on the data in Fig. 4 shows that optimal heating to produce large elongation is for 60 minutes. Elongation is also affected by the thickness of the film formed during the manufacturing process. If the film is thin, then the elongation will be low because the length of attraction that can occur the shorter or faster break.

The value of tensile strength generated fluctuates and looks almost the same. This indicates that the duration of heating does not significantly affect the value of tensile strength. However, the highest value of tensile strength is at 30 minutes of warming time. This can happen because on heating for 30 minutes with temperature above $70^{\circ} \mathrm{C}$, protein denaturation that has happened optimally so that new formation with plasticizer can be formed causing film characteristic more resistant to load voltage. When longer heated, instead reduce the value of its tensile strength. This can happen because the vibrations of molecules due to overheating heat make the bonds that have formed between the water-plasticizer protein can't be immediately docked causing saturation of the solution which can reduce the mechanical properties of bioplastic specimens. However, it does not mean that the low tensile strength value makes the specimen unfeasible to apply because every plastic product has different applications. 


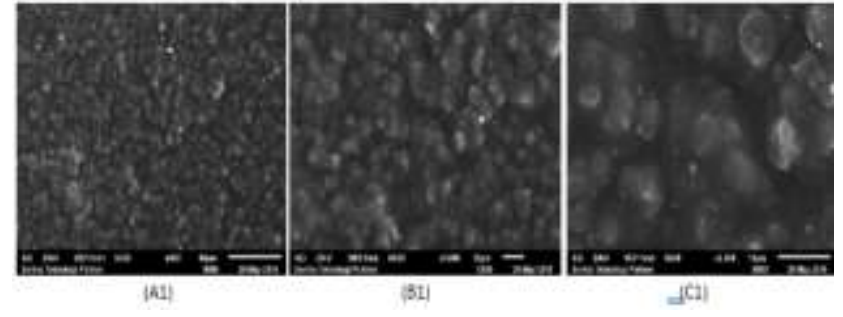

Fig. 5. SEM image of Treated Spirulina-PVA film Specimen with magnification (A1) 500x; (B1) 1000x; (C1) 2500x

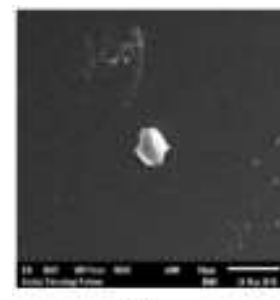

(A2)

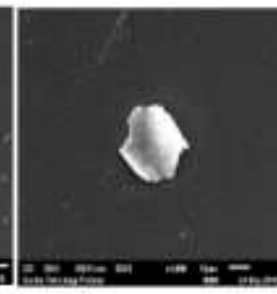

[a2.

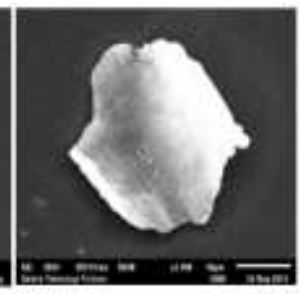

$-2+2$
Fig. 6. SEM image of Pure PVA with magnification (A1) 500x; (B1) 1000x; (C1) 2500x

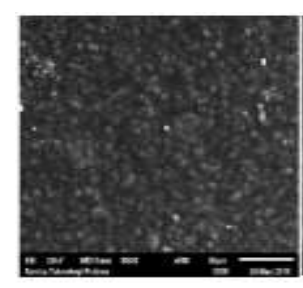

(A3)

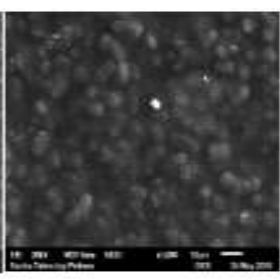

(B3)

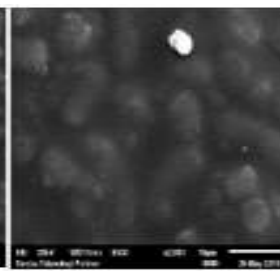

$=(3)$

Fig. 7. SEM image of Spirulina-PVA film Specimen nontreated with magnification (A1) 500x; (B1) 1000x; (C1) 2500x

\subsection{Morphology Characterization Analysis of Spirulina-PVA Bioplastic}

In Figure 6 which is a pure PVA control, most of the area looks the smoothest between the two other samples that Spirulina has mixed. This happens because PVA is a synthetic polymer that is definitely a polymer chain bond well structured. The surface in the control sample of Spirulina-PVA mixture without treatment as in Fig. 7 is smoother than the Spirulina-PVA thermoplastic sample with the treatment as shown in Fig. 5. However, in this Spirulina control sample seen cracks in some areas. This crack marks the process of plasticizing runs less than perfect because plasticizers can't be bound to proteins entirely and make new structures stronger and dispersion phase between Spirulina and plasticizer has not been good. In the meantime, although in the treated sample heated first, the surface was more rough and granular in appearance, but no cracked areas indicated that more plasticizers were binding to proteins before mixing with PVA.

\subsection{FT-IR Analysis}

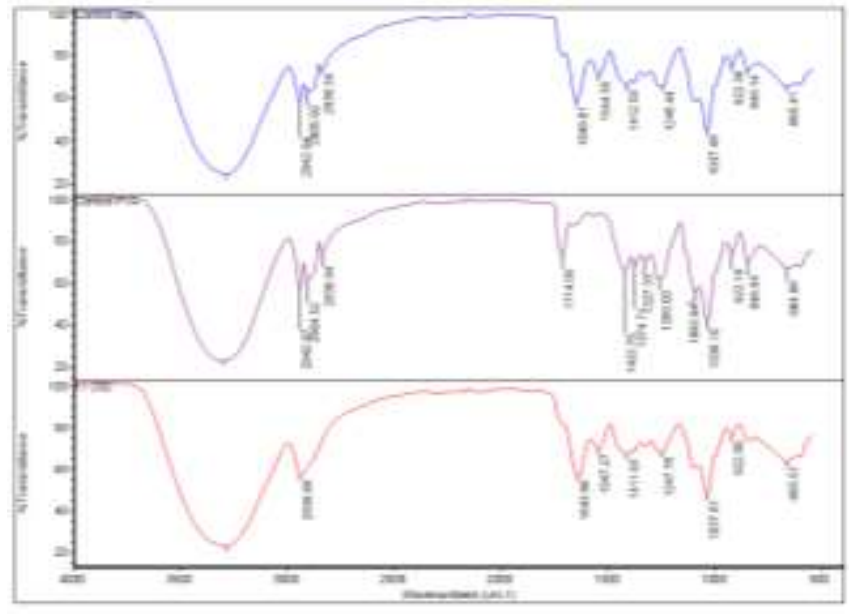

Fig. 8. FT-IR results Spirulina-PVA control specimen without treatment (above); pure PVA control (center); Spirulina-PVA with Treatment (below)

The results of FT-IR analysis of pure PVA control specimens show the characteristics of PVA spectra referring to Thomas et al. (2001). Basically the structure of PVA molecules consists of bonds $\mathrm{C}-\mathrm{H}, \mathrm{C}=\mathrm{O}, \mathrm{C}-\mathrm{C}$, and $\mathrm{O}-\mathrm{H}$. The largest peak is at a wavelength of $3300 \mathrm{~cm}^{-}$ ${ }^{1}$ in which this indicates the presence of an $\mathrm{O}-\mathrm{H}$ strain derived from the inter- and intramolecular hydrogen bonds. The peaks absorbed at the wavelengths 2942 and $2904 \mathrm{~cm}^{-1}$ signify the symmetry and vibration asymmetry of the $\mathrm{C} 1-\mathrm{C}$ alkyl group. The peak at the wavelength of $1714 \mathrm{~cm}^{-1}$ signifies the stretching of $\mathrm{C}=\mathrm{O}$ or ester in a pure PVA. The bonding dominance of $\mathrm{C}=\mathrm{O}$ indicates that the bond between the carbon is the alkane bond or $\mathrm{C}$ C.

In the Spirulina-PVA samples without treatment, there was absorption at wavelengths of $848 \mathrm{~cm}^{-1}$ which indicated the presence of a $\mathrm{C}-\mathrm{H}$ bond, but the wavelength value did not reappear in the treated Spirulina-PVA sample. This indicates that the $\mathrm{C}-\mathrm{H}$ group is lost due to a plasticizer disturbance and a solvent $\mathrm{pH}$ condition which forces $\mathrm{H}+$ to be removed so that equilibrium is reached and then replaced by a plasticizer. In Spirulina-PVA samples with or without heat treatment, there is absorption at the 1643 and $1649 \mathrm{~cm}^{-1}$ wavelengths indicating the presence of a beta-sheet structure in the secondary structure. If the content of beta-sheet and random coil is high in the sample, then the molecular structure of the protein is in a loose state [13]. This indicates that the polymer chains in proteins have been inserted by plasticizer molecules and synthetic PVA polymers.

\subsection{Thermal Analysis}

The TGA analysis can be used to investigate the effect of solvent $\mathrm{pH}$ treatment and the duration of heating on the thermal stability of proteins in Spirulina which also determines the thermal stability of the Spirulina-PVA bioplastic mixed specimens. Here are the TGA results presented in Figure 9. 


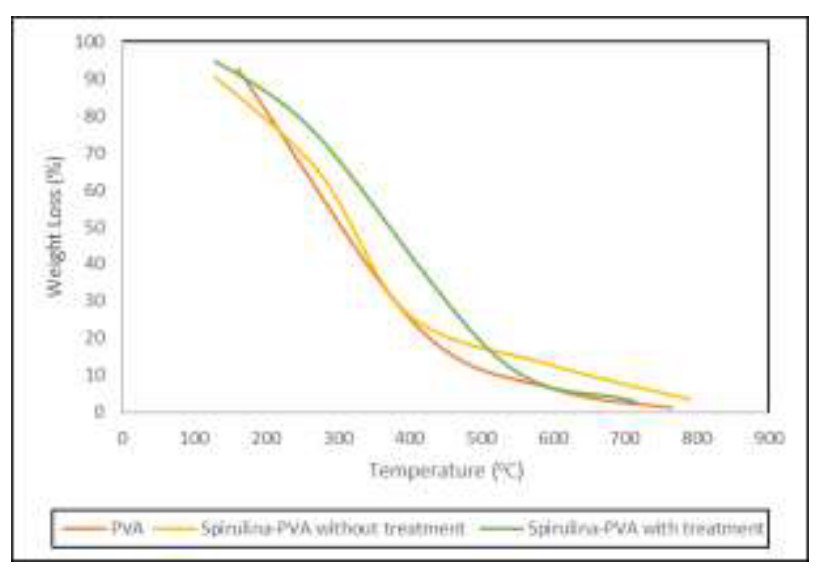

Fig. 9. TGA Result

Degradation after the temperature for the initial mass loss is achieved, occurs gradually. In the Spirulina-PVA sample by treatment, the first stage after the initial mass loss, occurs when the temperature reaches $270^{\circ} \mathrm{C}$ with a mass loss of $19.6 \%$. In the second stage, the mass loss occurs when the temperature reaches $525^{\circ} \mathrm{C}$ by $60 \%$. In the third stage, the mass loss occurs when the temperature reaches $715^{\circ} \mathrm{C}$ by $11 \%$. In a pure PVA control sample, degradation in the first stage occurs when the temperature reaches $410^{\circ} \mathrm{C}$ by $69 \%$. The second stage occurs when the temperature reaches $600^{\circ} \mathrm{C}$ by $16 \%$. In the third stage, degradation occurs when the temperature reaches $765^{\circ} \mathrm{C}$ by $5 \%$. In the spirulina-PVA control sample without treatment, degradation in the first stage occurs when the temperature reaches $275^{\circ} \mathrm{C}$ by $25 \%$. The second stage occurs when the temperature reaches $595^{\circ} \mathrm{C}$ by $13 \%$. In the third stage, degradation occurs when the temperature reaches $790^{\circ} \mathrm{C}$ by $9 \%$. Based on the above TGA data, it is shown that thermal degradation in Spirulina-PVA samples either with or without treatment occurs more rapidly than with pure PVA. This can happen because the Spirulina-PVA film specimen contains more degradable organic material. According to the research of [15], all thermal degradation occurring over $360^{\circ} \mathrm{C}$, indicates that the plastic contains non-cellulosic material. This corresponds to the degradation of the first phase of pure new PVA at a temperature of $410^{\circ} \mathrm{C}$.

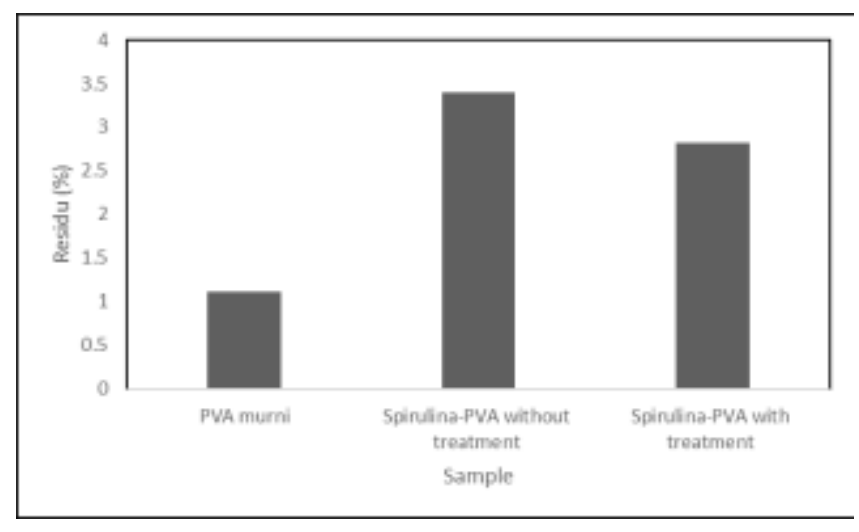

Fig. 10. Residual Comparison between Samples

In the treated sample, the amount of inorganic residue produced was lower than that of the unreacted sample indicating that the decomposed material was more in the sample by this treatment and the properties required by the bioplastic. When compared with pure PVA, the amount of residue in the Spirulina-PVA mixture is greater. This can happen because in the Spirulina-PVA mixture, the amount of organic matter is more due to the presence of Spirulina biomass, where organic matter contributes more carbon. Carbon can be derived from polysaccharides and proteins that are the largest content in Spirulina. This carbon-containing material can be left behind as a residue.

\section{Conclusion}

The best solvent to produce optimum mechanical properties is a solvent with a $\mathrm{pH}$ of 10 . Although the value of tensile strength is lower than at $\mathrm{pH} 11$, the elongation value is close to the elongation value in commercial plastics. Meanwhile, the best heating time to produce optimum mechanical properties is 60 minutes at a solvent $\mathrm{pH}$ above 8.5. If using a solvent $\mathrm{pH}$ below 8.5 , the best heating time is 120 minutes. Solvent $\mathrm{pH}$ is the most influential parameter on the bioplastic mechanical properties of Spirulina-PVA, while the heating time is less influential.

The authors gratefully thank the financial support from Universitas Indonesia through the Publikasi International Terindeks untuk Tugas Akhir Mahasiswa (PITTA) grant (No. 2416/UN2.R3.1/HKP.05.00/2018).

\section{References}

1. Avella, ME.2009. Eco-challenges of bio based polymer composite material. 2,911-925

2. Averous, L. (2008). Polylactic Acid: Synthesis, Properties and Applications. In L. Averous, Polylactic Acid: Synthesis, Properties and Applications (pp. 433-435). Amsterdam: Elsevier Ltd.

3. Chronakis, I. S. (2001) Gelation of edible bluegreen algae protein isolate (Spirulina platensis strain Pacifica): Thermal transitions, rheological properties, and molecular forces involved. Journal of Agricultural and Food Chemistry, 49, 888-898.

4. Darni, Yuli and Herti Utami. 2010. Preparation and Characteristics of Mechanical Properties and Hydrophobicity Bioplastics from Sorghum Starch. Journal Chemical and Environmental Engineering, Faculty of Engineering, University of Lampung Bandar Lampung. Vol.7, 4, Page 88-93

5. Falcone and Castelfranchi. 2004. Trust dynamics: How trust is influenced by direct experiences and by trust itself. In Proceedings of the 3rd International Conference on Autonomous Agents and MultiAgent System (AAMAS-04), New York, ACM. 
6. Jambeck, Jenna R., dkk. 2015. Plastic Waste Inputs from Land into The Ocean. Science 347 (6223), 768-771.

7. Jongkon, P; Siripen, T; Richard, D.L. 2008. The Optimum N: P Ratio of Kitchen Wastewater and Oil-Extracted Fermented Soybean Water for Cultivation of Spirulina platensis: Pigment Content and Biomass Production. International Journal of Agriculture and Biology.

8. Krochta, J.M. Proteins as raw materials for films and coatings: definitions, current status, and opportunities. In Protein-Based Films and Coatings; CRC Press: Boca Raton, FL, USA, 2002; pp. 1-41.

9. Liu, D. and Zhang, L. (2006), Structure and Properties of Soy Protein Plastics Plasticised with Acetamide, Macromolecular Materials and Engineering, 291, 820-828

10. McHugh, T. H., \& Krocht, J. M. (1994). Water Vapor Permeability Properties of Edible Whey Protein-Lipid Emulsion Films. California: Department of Food Science and Technology University of California.

11. Nahar, K. M; Zakaria, Z; Hashim, U.; Bari, F.M. 2017. Effect of $\mathrm{pH}$ and Salt Concentration on Protein Solubility of Slaughtered and NonSlaughtered Broiler Chicken Meat. Sains Malaysiana 46(5) (2017): 719-724.

12. Sothornvit, R.; Krochta, J.M. Plasticizer effect on mechanical properties of beta-lactoglobulin films. J. Food Eng. 2001, 50, 149-155.

13. Wang, K. (2014). Bioplastic Potential of Spirulina Microalgae. Athens: University of Georgia.

14. Wrigley, C.; Bietz, J.; Pomeranz, Y. Proteins and amino acids. In Wheat: Chemistry and Technology, 3rd ed.; American Association of Cereal Chemists: St. Paul, MN, USA, 1988; Volume I, pp. 159-275.

15. Yussuf, A.A., Massoumi, I. \& Hassan, A. J Polym Environ (2010) 18: 422. https://doi.org/10.1007/s10924-010-0185-0

16. Zhu, N., Ye, M., Shi, D., \& Chen, M. (2016). Reactive Compatibilization of Biodegradable Poly (butylene succinate)/ Spirulina Microalgae Composites. The Polymer Society of Korea and Springer.

17. Duangkanok Tanangteerapong, Patipan Prasathinpimai, Wasita Suebthamma, Khanita Kamwilaisak. 2016. The Potential of Rhodotorula graminis TISTR 5124 for Synthesis of Polyhydroxyalkanoate (PHA) by Limitation of a Phosphorus and Nitrogen Source. International Journal of Technology 7: 12141221. 